Año LI. urtea

$127-2019$

Urtarrila-ekaina

Enero-junio

5

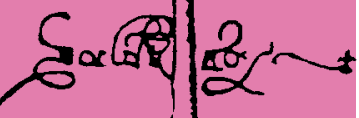

6

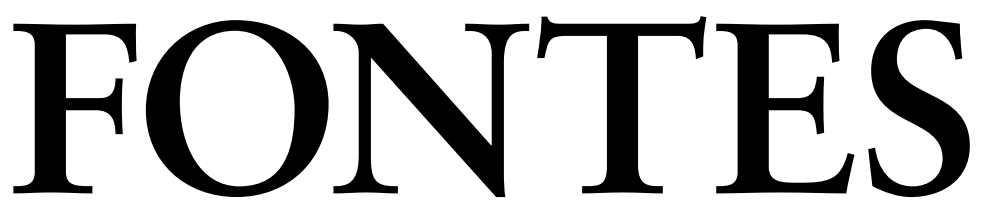

LINGVÆ

VASCONVM

STVDIA ET DOCVMENTA

SEPARATA

100 metroren azterketa

memoria ikasketen

ikuspegitik

Izaro Arroita AzKarate

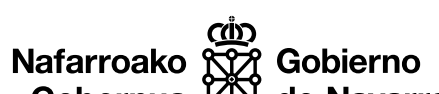

Gobernua \&S de Navarra

0000 


\title{
100 metroren azterketa memoria ikasketen ikuspegitik
}

$\overline{\text { Análisis de } 100 \text { metros (100 metro) desde la perspectiva de los estudios de la memoria }}$

An interpretation of 100 metro (100 meters) from the perspective of memory studies

Izaro ARROITA AZKARATE

Euskal Herriko Unibertsitatea (UPV/EHU)

izaro.arroita@ehu.eus

\begin{abstract}
Argitalpen hau IT 1047-16 ikertaldea burutzen ari den US 17/10 (UPV-EHU) eta FFI2017-84342-P (MINECO) ikerketa proiektuetan sartzen da. Halaber, Mari Jose Olaziregiren zuzendaritzapean eta Eusko Jaurlaritzaren ikertzaileak prestatzeko doktoradutza-aurreko laguntzari esker egindako doktore tesiko ikerlanaren emaitzak jasotzen ditu («Ramon Saizarbitoriaren nobelagintza memoria ikasketen ikuspegitik», EHU, 2015). Eskerrak ikerketan kide izan ditudan guztiei. Eta mila esker, bereziki, Ramon Saizarbitoriari, lan hau burutu ahal izateko eskuzabaltasunez emandako laguntzagatik.
\end{abstract}

Jasotze data: 2018/07/17. Behin-behineko onartze data: 2018/08/07. Behin betiko onartze data: 2018/08/16. 


\section{LABURPENA}

Lan honen xedea da Ramon Saizarbitoriaren 100 metro (1976) nobelaren irakurketa bat proposatzea memoriaren ikuspegitik. Horretarako, memoria ikasketetan funtsezkoak diren kontzeptu batzuk erabiliko ditugu, eta memoriaren errepresentazioa literaturan ikertzeko tresna analitikoak ere deskribatuko ditugu, narratologia kulturalaren esparruan. Memoriak funtzio ezberdinak betetzen ditu nobelan: heriotzaren aurrean protagonistari gogora datozkion oroitzapenek humanizatu egiten dute alferrik hiltzera doan gaztea. Beste plano batzuetan, gatazkaren eta zapalkuntzaren memoria komunikatiboaren sortze prozesua irudikatzen dute herritar anonimoen arteko elkarrizketa eta hitz aspertuek.

Gako hitzak: Saizarbitoria; 100 metro; memoria ikasketak; narratologia kulturala.

\section{RESUMEN}

El objetivo de este trabajo es analizar la novela 100 metros (1976) de Ramon Saizarbitoria desde la perspectiva de los estudios de la memoria. Para ello, nos valdremos de algunos conceptos fundamentales de los estudios de la memoria, así como de herramientas analíticas como la narratología cultural. La memoria cumple distintas funciones en la novela: los recuerdos del protagonista ante la muerte humanizan a ese joven que va a morir en vano. En otros planos, las conversaciones banales de los ciudadanos anónimos representan la creación y el funcionamiento de la memoria comunicativa del conflicto y de la represión.

Palabras clave: Saizarbitoria; 100 metro; estudios de la memoria; narratología cultural.

\section{ABSTRACT}

The main goal of this paper is to examine Ramon Saizarbitoria's novel 100 metro (1976) from the perspective of memory studies. In order to do so, we will describe some key concepts, and also some narratological tools that will give us a means of examining the literary representation of memory, which fulfils different functions in the novel: protagonist's individual memories in the face of death reveal a character that is used to losing, and this makes the fugitive more human. By means of the contrast between different narrative levels and voices, anonymous citizens' chitchats reflect the process of constructing and the functioning of communicative memory of the conflict and repression.

Keywords: Saizarbitoria; 100 metro; memory studies; cultural narratology. 
1. Sarrera. 2. Memoria kolektiboa, komunikatiboa eta kulturala. 3. MemoRIA ETA LITERATURA: MEMORIAREN ERREPRESENTAZIOAREN AZTERKETA LITERATUR TESTUETAN. 4. HERIOTZAREN AURREKO MEMORIA INDIBIDUALA 100 METRON. 5. MEMORIA KOMUNIKATIBOAREN SORKUNTZA: POLIFONIA ETA IKUSPEGI ANIZTASUNA 100 METRON. 6. ONDORIOAK. 7. ERREFERENTZIAK.

\section{SARRERA}

Ramon Saizarbitoriaren 100 metroren (1976) lehen argitalpenetik hogei urtera, hamargarren argitalpeneko (1997) hitzaurrean, nobelaren arrakasta eta berritasuna nabarmendu zituen Olaziregik; berritasuna edukiaren zein formaren aldetik, jakina denez, gatazkari buruzko lehen euskal nobelatzat hartu izan den honek kontateknika berriak ekarri zituelako euskal literaturara.

Beste hogei bat urte pasa dira ordutik, beste hainbat berrargitalpen izan ditu (azkenak, 2017an gaztelaniaz, eta 2016an euskaraz) eta gauza bera esan genezake; funtsezko irakurketa dela oraindik ere euskal irakurleentzat. Mugarria izan da, zalantzarik gabe. Esan genezake Saizarbitoria aitzindari izan dela, ez euskal literatura modernitatera eraman zuelako edo modernitatea euskal literaturara ekarri zuelako bakarrik; baita euskal gatazkaren kontaketari heldu ziolako eta memoriarekiko ardura lehen planora ekarri zuelako ere (nobela honetan eta ondorengoetan). 100 metro euskal literaturako nobelarik garrantzitsuenetako bat izan dela dio Aldekoak (2008, 261. orr.). Ingelesez argitaratu zen lehen euskal eleberria da, Hernandez Abaituak (2008, 188. orr.) dioenez (gaztelaniaz eta ingelesaz gain, italierara ere itzuli dute ${ }^{1}$ ), eta zinemarako moldatu zuen 1985ean Alfonso Ungria zuzendariak. «Euskal inkontziente kolektiboarentzat oso

1100 metroren itzulpenen inguruko informazio gehiago eskuratzeko, ikus Nor da Nor datu basea: http://nordanor.eus/bilatu? $=1 \&$ e_or $=\& e_{-} \mathrm{xt}=\& \mathrm{e}_{-} \mathrm{st}=100+$ metro\&e_eg=\&e_it $=\& e_{-}$ar $=\& \mathrm{e}_{-} g \mathrm{e}=\& \mathrm{e}_{-}$ $\mathrm{sh}=\&$ e_xh=\&e_sd $1=\&$ e_sd $2=\&$ e_xd1=\&e_xd2= 
garrantzitsua den zerbait» ukitzen duelako izan da hain arrakastatsua, Hernandez Abaituaren (2008, 261. orr.) hitzetan.

Irakurketa ezberdinak egin izan dira, noski, berrogei urteotan. Jakina denez, zentsura frankistarekin arazoak izan ostean argitaratu zen 100 metro, eta testuinguru hark baldintzatu egin zuen garai hartako irakurketa (Olaziregi, 2002; Hernandez Abaitua, 2008). Izan ere, Torrealdaik (2000) azaltzen duenez, zentsura frankistarentzat Gobernuaren eta poliziaren aurkako kritika onartezina zen nobela; hildako militantearen apologia. Beraz, lehen edizioa bahitu zuen poliziak epailearen aginduz. Euskal irakurle batzuek, berriz, «eleberri abertzalea» ikusi nahi izan zuten (Olaziregi, 2002, 88. orr.). Eta poliziak lehen edizioa bahitzeak entzute handia eman ziolako, «berriro zirkulazioan jarri zenean barra-barra saldu zen. Lehen euskarazko best-sellerra izan omen zen», Hernandez Abaituak dioenez (2006, 81. orr.).

Kritikari dagokionez, nobelaren alderdi formalari erreparatu izan zaio, batez ere. Gogora dezagun, esaterako, fokalizazioa ardatz hartuta ikertu zuela Olaziregik (1991), edota narratologiaren ikuspuntutik aztertu zuela Saizarbitoriaren lehen eleberrigintza Hernandez Abaituak (2008). Abiapuntu izango ditugu ikerlan horiek, memoria ikasketen ikuspegitik egindako irakurketa honetan.

Forma eta edukia aintzat hartuta, eta Saizarbitoriaren nobelagintzan (eta, oro har, azken aldiko euskal literaturan) gatazk(ar)en kontaketak izan duen zentraltasuna kontuan izanik, gatazkaren errepresentazioari erreparatuko diogu artikulu honetan. Zehazkiago, gatazkari lotuta, memoria indibidual zein kolektiboa nola irudikatzen diren aztertzea izango da gure helburu nagusia. Horretarako, memoria ikasketetako kontzeptu batzuk, azterketa honetan baliatuko ditugunak, azalduko ditugu lehendabizi, eta memoriaren eta literaturaren arteko loturaz jardungo dugu gero, corpus literario bat memoriaren ikuspegitik ikertzeko erabil ditzakegun tresna analitikoak deskribatzeko.

\section{MEMORIA KOLEKTIBOA, KOMUNIKATIBOA ETA KULTURALA}

Azken urteotan memoriaren booma eta globalizazioa izan dugula diote adituek (Huyssen, 2003). Memoriari buruzko diskurtsoen zabaltze eta ugaritze horretan, asko eta askotarikoak izan dira hainbat diziplinatatik (historiografiatik, soziologiatik edota artearen mundutik, besteak beste) egin diren ekarpenak. Zalantzarik gabe, diziplinarteko eremu oparoa da, gaur egun, memoria ikasketena.

100 metroren irakurketa hau egiteko, eremu honetan aitzindari izan den egile baten lana hartuko dugu abiapuntu; Maurice Halbwachs soziologoarena, hain zuzen ere. Bere ekarpenik garrantzitsuena, memoria kolektiboari buruzko lana, XX. mende hasieran garatu zuen, Henri Bergson-en eta Emile Durkheim-en eraginpean, batez ere. Bere liburu ezagunenetako bi aipatuko ditugu; bata, Les cadres sociaux de la mémoire, 1925ean argitaratua, eta bestea La mémoire collective (1950), hilondoko argitalpena, Buchenwald-eko kontzentrazio esparruan hil baitzen Halbwachs 1945ean. 
Labur esanda, Halbwachsek azaltzen du gure oroitzapenak kolektiboak direla, baita norberarenak edo indibidualak diruditenean ere, oroitze prozesu oro baldintzatzen duelako testuinguru sozialak. Izan ere, taldetik, gizartetik jasotzen ditugu gure hautematea baldintzatzen eta moldatzen duten ezagutza eta pentsamoldeak, eskema kognitiboak, kultura, oro har. Beraz, taldetik jasotako memoria kolektiboaren araberakoa da, ikuspegi honen arabera, iraganeko gertakariak gogoratzeko eta interpretatzeko ahalmena:

L'individu évoque ses souvenirs en s'aidant des cadres de la mémoire sociale. En d'autres termes les divers groupes en lesquels se décompose la société sont capables à chaque instant de reconstruire leur passé. Mais, nous l'avons vu, le plus souvent, en même temps qu'ils le reconstruisent, ils le déforment (Halbwachs, 1994 [1925], 289. orr.).

Gizarteko hainbat taldetako kide izaten garela azaltzen du Halbwachsek, eta talde jakin bateko kide garen heinean, talde horretan inplikatuta gauden heinean, iraganeko oroitzapen batzuk partekatzen ditugula gainerako taldekideekin. Osatu, zehaztu nahiz distortsionatu egiten dira oroitzapenak. Baina gogoratu ahal izateko, iragana berregiteko, ezinbestekoa da taldearen ikuspegia izatea eta pentsamendu kolektibo horren edo horien korronteari jarraitzea (Halbwachs, 1968 [1950], 15. orr.). Horregatik, Halbwachsen arabera, taldearen iraupena da memoria bermatzen duena, eta, alderantziz, ahanzturak esan nahi du desagertu egin dela taldea edo, norbanakoaren kasuan, galdu egin duela talde jakin horrekiko harremana.

Testuinguru sozialaren araberakoak dira, beraz, memoria indibidualak, eta memoria kolektiboaren gaineko ikuspegi bat eskaintzen digute, taldekideak, norbanakoak direlako, azken finean, oroitzen dutenak; hau da, norbanakoen memorietan azaleratzen delako memoria kolektiboa. Kide bakoitzak taldean duen lekuaren arabera aldatuko da, noski, memoria kolektiboaren gaineko ikuspuntu hori; eta aldatu egingo da norbanako horrek beste talde batzuekin dituen harremanen arabera ere. Perspektiba aniztasun horrek azalduko lituzke, Halbwachsen arabera, memoria kolektiboaren baitako aldaerak. Baina, edonola ere, aniztasun horren atzean, beti dago taldearen edo gizartearen eraginen konbinazio bat (Halbwachs, 1968 [1950], 33. orr.).

Talde baten edo oro har gizartearen memoria kolektiboari dagokionez, berriz, Halbwachsek dio gizarte baten biziraupenerako ezinbestekoa dela bere erakundeak sineste kolektibo sendoetan oinarritzea. Sineste horiek izaera bikoitza dute: alde batetik tradizioak dira, iraganari lotutako oroimen kolektiboak; baina, bestetik, orainaldiko ezagueraren araberako ideiak eta egiuneak dira orobat:

D'où il résulte que la pensée sociale est essentiellement une mémoire, et que tout son contenu n'est fait que de souvenirs collectifs, mais que ceux-là seuls parmi eux et cela seul de chacun d'eux subsiste qu'à toute époque la société, travaillant sur ses cadres actuels, peut reconstruire (Halbwachs, 1994 [1925], 296. orr.).

Oraina eta iragana batzen ditu, beraz, memoria kolektiboak, taldeak orainaldian dituen behar eta interesen arabera eraikitzen delako. Izan ere, gizartea garai eta egoera berrietara moldatzen da, eta horren araberakoak izango dira iraganaren errepresentazioak 
ere (Halbwachs, 1994 [1925], 279. orr.). Etengabeko berregite eta birmoldatze horrek, iraganaren kontzientzia kolektibo horrek, jarraikortasuna ematen dio taldeari, hau da, identitate kolektiboaren sorkuntzan eragiten du zuzenean (Halbwachs, 1968 [1950], 77. orr.).

Kontuan izan behar da, Colmeirok (2005, 16. orr.) azaltzen duenez, hainbat kritikarik gehiegizkotzat jo duela Halbwachsek memoria ororen sorkuntzan gizartearen eraginari ematen dion garrantzia, norbanakoaren memoriak ezeztatzera iristen delako. Baina memoria indibidual eta kolektiboen arteko ezberdintasunak eta elkarreragina onartuta, horixe da, Colmeiroren arabera, Halbwachsen ekarpenik garrantzitsuenetakoa: «El legado principal de Halbwachs reside en su visión de la función de la sociedad como cuadro conceptualizador y espacio reflector de la memoria» (Colmeiro, 2005, 16. orr.). Memoria kolektiboaren ulerkera hori Althusser-en «ideologia» kontzeptuaren antzekoa da, Colmeirok dioenez, taldea legitimatzen duen ideia-sistema gisa azaltzen delako. Lokailu funtzioa betetzen du, beraz, memoria kolektiboak ikuspegi honen arabera.

Halbwachsen ekarpenaren ildoan, hainbat ikerlarik garatu du memoria kolektiboaren inguruko teorizazioa. Horien artean, baliagarria da, besteak beste, Aleida eta Jan Assmann-ek proposatu duten oinarrizko bereizketa; memoria komunikatiboa eta kulturala ezberdindu dituzte, hain zuzen ere.

Memoria komunikatiboa eguneroko komunikazioan oinarritzen den memoria kolektiboa da, eta ahozko historiari dagokio. Denbora tarte mugatua hartzen du, laurogei edo ehun urte artekoa, hau da, hiru edo lau belaunaldi. Eguneroko komunikazioa ez da espezializatua eta elkarrekiko harremanean moldatzen da. Aldakorrak dira, beraz, memoria komunikatiboaren edukiak eta, askotan arau sozialek komunikazio edo truke hori mugatzen duten arren, funtsean ez dago forma edo antolabide sendorik. Beraz, ikuspegi honen arabera, memoria komunikatiboak ez dio oinarri edo euskarri finkorik ematen taldeari bere iraganarendako:

The communicative memory offers no fixed point which would bind it to the ever expanding past in the passing of time. Such fixity can only be achieved through a cultural formation and therefore lies outside of informal everyday memory (Assmann, 1995, 127. orr.).

Memoria komunikatiboaren aldean, memoria kulturalak esperientzia kolektiboaren gauzatzea edo objektibatzea adierazten du. Askoz denbora tarte zabalagoa duen iragan mitikoari lotuta dago, eta finkatuago daude edukien transmisioa eta interpretazioa. Memoria komunikatiboa baino instituzionalizatuago dago, beraz, memoria kulturala, testu, erritu edota zeremoniei lotua:

Cultural memory has its fixed point; its horizon does not change with the passing of time. These fixed points are fateful events of the past, whose memory is maintained through cultural formation (texts, rites, monuments) and institutional communication (recitation, practice, observance) (Assmann, 1995, 129. orr.).

Objektibatutako kulturaz aritzeak pentsaraz diezaguke memoriaren alorra utzi eta historiarenean sartu garela. J. Assmannek, baina, aurka egiten dio uste honi, 
argudiatuaz objektibatutako kulturak memoria gisa funtzionatzen duela talde nortasunaren sorkuntzari dagokionez (Assmann, 1995, 128. orr.). Izan ere, dioenez, kultura ondarearen bidez bilakatzen da gizarte bat ikusgai bere buruarentzat eta besteentzat. Jasotako ezagutzari esker hartzen du taldeak talde izatearen kontzientzia, eta horren arabera berregiten du bere nortasuna:

The concept of cultural memory comprises that body of reusable texts, images, and rituals specific to each society in each epoch, whose «cultivation» serves to stabilize and convey that society's self-image. Upon such collective knowledge, for the most part (but not exclusively) of the past, each group bases its awareness of unity and particularity (Assmann, 1995, 132. orr.).

J. Assmannek bezala, beste ikerlari batzuek ere garatu dute Halbwachsen teoria, antzeko banaketak proposatuaz. Erll-ek (2011, 30. orr.) azaltzen duenez: milieux de mémoire eta lieux de mémoire (Pierre Nora), 'herri memoria' eta 'memoria ofiziala' (John Bodnar) edota 'bizi izandakoaren memoria' eta 'memoria urruna' (William Hirst \& David Manier). Azken finean, garai bertsuko eta aspaldiko gertakarien memorien arteko ezberdintasuna hartzen da kontuan; oroimen modu 'ofizialen' edo 'ez-ofizialen' artekoa; egunerokotasunari eta gaurkotasunari lotutako memoria aldakorren edo esanahiz betetako tradizioen artekoa; edota ahozkotasunari dagozkion oroimen moduen eta bitarteko garatuagoak behar dituztenen artekoa. Emankorra dirudi, beraz, Halbwachsen teoria ildo horretan garatzeak.

Hala ere, Erllek ohartarazten duenez, J. Assmannek proposatutako definizioa ulertzeko kontuan izan behar da kultural adjektiboaren atzean kulturaren ulerkera mugatu bat dagoela, kultura jaso instituzionalizatuari lotuago dagoena eguneroko herri kulturari baino: "'Cultural Memory' does therefore not describe all manifestations of 'memory in culture'; rather it represents a subset of this: the societal construction of normative and formative versions of the past» (Erll, 2011, 30. orr.). Nolanahi ere, memoria komunikatiboa eta kulturala, biak dira fenomeno kulturalak, kultura zentzu antropologiko zabalean hartuta.

Memoria mota horien sorrera eta bilakaera ulertzeko, garrantzitsua da gizarte adierazpideei erreparatzea. Lan honetan literatura izango dugunez aztergai, memoriaren eta literaturaren arteko harremana aztertu duten ikerlarien lanak aipatuko ditugu jarraian. Literaturak, testuinguru soziokultural jakin batean sortzen den adierazpide artistiko gisa, memoria eta identitate kultural ezberdinak irudikatzeko izan ditzakeen berezitasunak hartuko ditugu aintzat.

\section{MEMORIA ETA LITERATURA: MEMORIAREN ERREPRESENTAZIOAREN AZTERKETA LITERATUR TESTUETAN}

Fikziozko lanetan memoriak nola irudikatzen diren aztertu duten ikerlanak ugaritu dira azken urteotan, memoriaren boomarekin batera, eta argi geratu da, Erllen (2011) arabera, memoriak literaturan (narrazio testuetan, bereziki) duen garrantzia, gaiari 
nahiz egiturari dagokienez. Kontuan izan behar da, egile honek azaltzen duenez, literaturak bereizgarri garrantzitsuak dituela memoria kulturalean eragiten duten beste forma sinboliko batzuekin alderatuta (historiografiarekin, lege testuekin, mitologiarekin edota erlijioarekin alderatuta, esaterako).

Bereizgarri horien artean, nagusienetakoak dira fizkiozkotasunak dakartzan abantailak eta mugak. Iraganeko gertakariak irudikatzean, fikziozko lanek beste testu mota batzuek baino errazago adieraz dezakete pertsonaia baten kontzientzia, eta frogatu gabe dauden elementuak edo asmazio hutsak direnak ere sar ditzakete narrazioari indarra emateko. Bestalde, mugatuagoa izan ohi da fikziozko lanen erreferentzialtasuna eta objektibotasuna.

Literaturaren beste bereizgarrietako bat 'diskurtsoartekotasuna' da, Erllen (2011) arabera. Bakhtin-en teorian oinarrituta azaltzen duenez, 'heteroglosiak' ezaugarritzen ditu literatur lanak, hizkera eta diskurtso ezberdinak adierazten direlako testu berean. Horietako bakoitzak ikuspuntu bat, mundu ikuskera bat testuratzen du eta, bata bestearen ondoan, harreman dialogikoan, diskurtsoak elkarren osagarri edo elkarren kontrako izan daitezke. Memoriei dagokienez ere, ikuspegi aniztasuna eskain dezake literaturak:

By representing different ways of speaking about the past (and of memory), literature gives voice to the epistemological and ideological positions connected with these languages. In this way, literary works can display and juxtapose divergent and contested memories and create mnemonic multiperspectivity. In a world of increasingly specialized -and separated- discourses (such as those of history, theology, economy, and law), literature thus also acts as a 'reintegrative interdiscourse' (Link 1988), as a medium which brings together, and re-connects, in a single space the manifold discrete parlances about the past (Erll, 2011, 150-151. orr.).

Beraz, memoria ezberdinak, osagarriak, anbiguoak, elkarren aurkakoak adierazteko gaitasuna du literaturak, eta konplexutasun horretatik datorkio, hain zuzen ere, bere indarra eta potentzial afektiboa (Erll, 2011, 151. orr.). Ildo beretik dio Neumannek (2010, 338-339. orr.) ere literaturak, ikuspegi aniztasunaren bidez, ikusgarri egin ditzakeela memorien arteko gatazkak edota baztertuak izan direnen memoriak, eta beraz, 'kontra-memoria' funtzioa bete dezakeela, diskurtso hegemonikoa zalantzan jarriaz. Rothberg-en (2009) hitzak geure eginaz, esan genezake memoriaren 'multidirekzionaltasuna' irudika dezakeela literaturak; hau da, memoria ezberdinek elkarrekiko harremanean sortzen dituzten kulturarteko dinamika berriak adieraz ditzakeela, memorien arteko elkarreraginak edota negoziazioak.

Hori testuetan nola gauzatzen den aztertzeko, hau da, memorien irudikapena interpretatzeko, errepresentazio estrategia zehatzei eta horien testuinguruari erreparatu behar zaie. Horretarako, ikuspegi narratologikoa lagungarri izan daitekeela defendatzen du Erllek. Ildo beretik, narrazio testuak interpretatzeko kategoria malguak eskain ditzakeen eta testuingurua kontuan hartuko duen narratologia kulturalaz dihardu Nünning-ek (2004) ere. Ez dute, beraz, narratologia klasikoa proposatzen, erabilera zabalago bat baizik, narratologiatik hartutako tresna analitikoak ikasketa kulturaletan 
baliatzeko. Alde batetik, eleberrien eta bere testuinguru kulturalaren arteko harremana aztertzeko baliabide berriak eskain ditzake erabilera horrek; bestetik, estrategia narratiboen inplikazio epistemologiko, historiko kultural eta ideologikoak ulertzen lagun dezake.

Narratologia klasikoa egokitzeko bide horretan, Bal-en $(1990,1999)$ lanak erakusten digu ikuspegi narratologiko batetik azter daitekeela narrazio gisa interpreta dezakegun edozein elementu kultural; kritika feminista egiteko erabili izan du berak. Ildo horretan, Nünningek (2004, 356. orr.) dioenez, narratologia berri horiek (narratologia feministak edo postkolonialak, esaterako) tresna baliagarriak eskain ditzakete forma narratiboak indar kognitibo aktibo gisa aztertzeko, eta ulertzeko nola eragin dezakeen literaturak jarrera, diskurtso, ideologia, balio eta pentsamoldeen sorkuntzan.

Ikuspegi horren arabera, narrazio testuen ezaugarri formalak esanahiz beteta ageri dira, zama semantiko handia dute (Nünning, 1997). Noski, hainbat ezaugarri izan daitezke esanguratsuak narrazio testuen azterketan; Erllek bereziki nabarmentzen ditu narratzailearen ahotsa, fidagarritasun maila eta fokalizazioa, eta baita kronotopoa eta memoriaren inguruko metaforak ere (Erll, 2011, 158. orr.). Genette-ren lanean oinarrituaz azaltzen du, esaterako, denbora aztertzeko kategoria narratologikoak (ordena, iraupena eta maiztasuna) baliagarriak izan daitezkeela oroimen prozesuak nola irudikatzen diren ikertzeko ere:

Viewed from a memory-studies perspective Genette's very detailed introduction of the categories 'order', 'duration' and 'frequency' seems not accidental but dependent precisely on the choice of his major example. A la recherche du temps perdu is a 'novel of and about memory', a novel which is based on the narrator's act of remembering and which minutely observes and problematizes the processes of memory, that is, the act of connecting different time levels. Not surprisingly then, Genette's categories of narratological time analysis are also apt descriptions for major memory processes (Erll, 2009, 214. orr.).

Oroitzean, iragana berregitean, ohikoak izaten dira analepsiak eta prolepsiak; gertakari garrantzitsuak eta, batez ere, traumatikoak direnak errepikatu egiten dira gogoan eta, aldiz, ohiko gertakari arruntak laburbildu egiten dira edo modu iteratiboan azaltzen (Erll, 2009, 214. orr.). Narratzailearen fidagarritasun mailari dagokionez, fidagarria ez den narratzaileak -bere zalantzek, anbiguotasunak edota kontraesanek-, memoria arazoak adieraz ditzakete; iragana berreskuratzeko zailtasunak (Erll, 2009, 223. orr.).

Ildo beretik dio Neumannek (2010, 336-340. orr.) memoriari buruzko fikziozko lan garaikide gehienetan denbora plano ezberdinak tartekatzen direla, eta denbora batetik besterako garapenak ez diola ordena kronologikoari jarraitzen, esperientzia subjektiboari baizik. Anakronia horrek memoriaren funtzionamendua irudika lezake Neumannen iritziz. Bestetik, narratzaile homodiegetikoa agertzen denean, askotan, memoria eta identitate indibidualen arteko harreman konplexua adieraz dezake bizi izandakoa oroitzen eta lehen pertsonan kontatzen duenak, izan zenaren eta gogoratzen duenaren arteko tenka sortzen delako maiz. Iraganaren berreskuratze hori indibiduala baino 
areago kolektiboa denean, berriz, Neumannek dio fokalizazioak adieraz dezakeela memoria eta identitate kolektiboen sorkuntzan gertatzen den negoziazioa, edo memoria ezberdinen arteko talka, besteak beste, ikuspuntu aniztasunaren bidez. Testuartekotasuna ere esanguratsua izan daiteke zentzu horretan.

Beraz, narrazio testuen ezaugarri formalak aintzat hartuta, errepresentazio moduen eta memoriaren arteko loturak aztertu dituzte egile horiek. Lan honen helburua ez da Saizarbitoriaren nobelaren azterketa narratologiko hertsi bat egitea, baina lagungarri izango zaizkigu memoria ikasketetarako tresna analitiko horiek proposatzen dituzten ekarpenok, memoria ezberdinak nola irudikatzen diren aztertzeko eta errepresentazio modu horien inplikazioak interpretatzeko.

\section{HERIOTZAREN AURREKO MEMORIA INDIBIDUALA 100 METRON}

Jakina denez, etakide baten azken ehun metroak kontatzen ditu aztergai dugun nobelak. Ihesi doala, poliziak tirokatuta hilko da, Donostiako Konstituzio plazan. Interesgarria da ohartzea haurtzaroko eta gaztaroko oroitzapenak datozkiola gogora protagonistari heriotzaren aurrean, bortizkeriak markatutako orainean. Memoria indibidual horrek zer ezaugarri dituen, nola testuratzen den eta kontakizunean zer funtzio betetzen dituen aztertuko dugu atal honetan.

Esan genezake memoria episodikotzat har genitzakeenak izango ditugula bereziki aztergai. Izan ere, psikologiaren esparruan bereizi egiten dira memoria semantikoa eta episodikoa. Lehenak ikasketaren bidez geureganatu dugun ezagutza kontzientea dakarkigu gogora, eta ez dago denbora eta testuinguru jakin bati lotuta. Bigarrenak, berriz, norberak bizi izandakoarekin dauka zerikusia; atzera garamatza denboran iraganeko bizipenetara, eta beraz, biziki afektiboa da (Erll, 2011, 84-85. orr.). Ildo horretan, Hamleten irudikatzen diren memoria mota ezberdinen azterketaren harira A. Assmannek dioenez, memoria episodikoak sakontasuna ematen dio protagonistari:

It is a lively and sensuous image, it is a fragmentary scene, lacking a narrative struc-
ture, and it is tinged with nostalgic sentiment. It is not the product of a conscious re-
flection but rather a passive memory that is involuntarily triggered by an external
object. This flash of personal remembrance does not fulfil any function in the plot or
in the overall structure of the play; it is, rather, a contingent and fragmentary piece of
information that tightens the atmosphere and gives psychological depth to the main
character (Assmann, 2004, 331. orr.).

Ikusiko dugunez, protagonista ezaugarritzeko baliabide garrantzitsuenetakoa da memoria indibiduala 100 metron. Heriotzaren aurrean gogora datozkion haurtzaroko oroitzapenek sakontasun psikologikoa ematen diote iheslariari eta, batez ere, humanizatu egiten dute. Bereziki esanguratsuak dira, zentzu horretan, fokalizazioarekin egiten den jokoa eta protagonistaren hilketaren kontakizunean txertatzen diren analepsiak. Horiek aztertzeko, abiapuntu interesgarria eskainiko digute Olaziregik (1991, 2001) eta Hernandez Abaituak (2008) egindako azterketa narratologikoek. 
Nobelaren egitura zatikatua eta plano narratibo ezberdinen erabilera nabarmentzen dute biek, baita joera objektibista eta zinemagintzako tekniken erabilera ere: «Irudi panoramikoak, travelling luzeak edo kamera geldoan egindako plano nagusiaren narrazioa dira esandakoaren adierazle»(Olaziregi, 2002, 88. orr.). Formaren garrantzia azpimarratzen du, beraz, Olaziregik, eta narratzaileak objektibotasunez kontatzen duela, pertsonaien analisi psikologikoa baztertuaz (Olaziregi, 2002, 87. orr.).

Hernandez Abaituak (2008, 191. orr.) azaltzen duenez, berriz, plano eta ahots askok osatzen duten puzzle edo collage bat da nobela, eta zati batzuen eta besteen arteko elkarreraginak osatzen eta indartzen du kontakizuna; etakidearen heriotza. Txandakatzen diren sei plano edo azpidiskurtso hauek bereizten ditu, nobelan agertzen diren ordenan (Hernandez Abaitua, 2008, 195- orr.):

A: haur bat fraide-ikastetxe batean

B: polizia batzuek estudiante bati egiten dioten itaunketa

C: iheslariaren hilketaren albistea

D: iheslariaren jazarpena eta hilketa

$\mathrm{d}$ : iheslariaren analepsiak

E: Donostiako kaleetako giroa hilketaren ostean (eta hurrengo egunean)

F: Donostiari buruzko informazio turistikoa ${ }^{2}$.

Olaziregiren (1991, 50. orr.) arabera, berriz, bost dira plano narratiboak. Ikus dezakegunez, ezberdin ordenatzeaz gain, batu egiten ditu kaleko jendearen iruzkinak eta Donostiari buruzko informazio turistikoa (E), eta ez ditu bereizten protagonistaren ihesa eta ihesean gogora datozkion oroitzapenak (Hernandez Abaituaren D eta d):
A- Ihesaren kontakizuna
B- Ikasle gazteari eginiko galdeketa
D- Egunkariko berriak
E- Kaleko jendearen iruzkinak
F- Eskolako haurraren kontakizuna

2 Kortazarren (1980) sailkapenarekin bat egiten du Hernandez Abaituarenak, gutxi gorabehera; besteak beste, azken azpidiskurtsoa gehituta, hau da, Donostiari buruzko informazio turistikoa. 
Bi proposamenon arteko erdibidea komeni zaigu azterketa honetarako. Batera aztertuko ditugu ihesaren kontaketa eta protagonistari burura datozkion oroitzapenak (Hernandez Abaituaren $\mathrm{D}$ eta d). Alabaina, bereizi egingo ditugu herritarren erreakzioak eta Donostiari buruzko informazio turistikoa (Hernandez Abaituaren E eta F), diskurtso mota bakoitzaren ezaugarriak esanguratsuak iruditzen zaizkigulako memoriaren ikuspegitik egindako irakurketa hau bideratzeko orduan. Planoen bereizketa hau erabiliko dugu, beraz, Olaziregiren eskemari hiriaren deskribapen turistikoa gehituta:

A. Militantearen ihesaren kontakizuna (eta bere oroitzapenak)

B. Ikasle gazteari eginiko galdeketa

C. Militantearen hilketaren albistea

D. Kaleko giroa eta jendearen iruzkinak

E. Donostiari buruzko informazio turistikoa

F. Eskolako haurrari buruzko kontakizuna

A da eleberriko plano nagusia, istorioaren mamiari dagokionez, eta baita orri kopuruaren aldetik ere (Hernandez Abaitua, 2008, 196. orr.). Plano horri helduko diogu hasteko, heriotzaren aurrean azaleratzen den memoria aztertzeko. Bereziki erreparatuko diegu ihesaren kontakizunaren fokalizazioari eta oroitzapenak testuratzen dituzten analepsiei.

100 metro nobelako fokalizazioaren azterketa egin du Olaziregik (1991), Gérard Genetteren proposamen teorikoari Mieke Balena eta Boris Uspensky-rena gehituta. Jakina denez, Genettek (1972) bereizi egiten ditu ahotsa (nork kontatzen du?) eta ikuspuntua (nork ikusten du?), eta azken horri dagokionez, ezberdindu egiten ditu zero fokalizazioa (edo kontaketa ez fokalizatua), barru fokalizazioa (finkoa, aldakorra edo anizkuna) eta kanpo fokalizazioa.

Ikusi dugunez, fokalizazioa bereziki esanguratsua izan daiteke (beste kontzeptu narratologiko batzuen artean) testu mota ezberdinak (narrazio gisa interpreta daitekeen edozein elementu kultural) aztertzeko eta irakurketa ideologikoago bat egiteko; hau da, kulturaren ikerketa narratologikoa nahiz narrazioen irakurketa kulturala burutzeko (Nünning, 2004; Erll, 2011). Izan ere, Uspenskyren lanean oinarrituta Olaziregik (1991) azaltzen duenez, fokalizazioa ekintza semiotikoa da, eta kontuan hartu behar dira pertzepzio mota desberdin horietan alderdi emotibo, kognitibo eta ideologikoak ere.

100 metroko A plano nagusian, iheslaria da, batez ere, ekintza fokalizatzen duena. Hala ere, fokua barrutik kanpora mugitzen da maiz, eta kanpo fokalizazioa nagusitzen denean, ikusmira panoramiko zabala eskaintzen zaigu, fokua oso goian kokatuta (Olaziregi, 1991, 56. orr.). Ez da, ordea, fokua bakarrik aldatzen; narratzaileak darabiltzan 
pertsona gramatikala eta denbora ere etengabe aldatzen dira A planoan, bigarren pertsonatik hirugarrenera eta orainalditik iraganaldira. Olaziregik dioenez, bigarren pertsona gramatikal hori «lehenengo pertsona destolestua» da (Olaziregi, 2001, 20. orr.).

Ildo beretik azaltzen du Hernandez Abaituak (2008, 222. orr.) bigarren pertsona gramatikala «nolabaiteko lehen pertsona mozorrotua» dela. Bigarren eta hirugarren pertsonak nahasteak ahalbidetu egiten du narrazioari eite objektiboa ematea (narratzaile orojakile klasikotik urrunduz), eta aldi berean, pertsonaiaren kontzientzian erraztasunez sartzea. Beraz, fokuaren eta narratzaileak darabilen pertsona gramatikalaren aldaketen ondorio nagusienetakoa da posible dela, fokua nagusiki iheslariarengan dagoen arren, kanpotik, ikuspegi objektiboago batetik ere kontatzea.

Adibide gisa aipatzen du Hernandez Abaituak (2008, 225. orr.) ihesaldiaren kontakizunean orainaldiko bigarren pertsona gramatikala (singularrean, hitanoan) nagusitzen bada ere, hirugarren pertsona gramatikala darabilela narratzaileak polizien posizioaz hitz egiterakoan; kanpotik kontatu behar du, atzetik doazkiolako iheslariari eta, beraz, honek ezin dituelako ongi ikusi: «Dena den, ez duk, ez du burua bueltatzen. Arkupetik gero eta gehiago aldenduz -Aiuntamentua eskuin-aldera utziaz- 'Zamudio'ren terrazarantz zuzentzen ditu pausoak. Atzekoak berriz basket-ekipo baten formazio eran abantzatzen dute» $(15 \text {. orr.) })^{3}$. Olaziregiren $(1991,56$. orr.) arabera, saskibaloiko terminologia horrek («pivota» ere aipatzen da, esaterako, 37) kanpo fokalizazio objektiboa nabarmentzen du eta dramatikotasuna kentzen dio narrazioari.

Bestalde, interesgarria da ohartzea, A planoko narratzaileak kontakizunaren fokua iheslariaren barruan nahiz kanpoan kokatzeko ahalmena izan arren, ezin duela gauza bera egin iheslariaren heriotzaren lekuko diren pertsonaiekin eta, zehazkiago, poliziekin. Adibide esanguratsua eskaintzen du, ildo horretan, 38. orrialdeko oin-oharrak. Atzetik doazen polizien kokagunearen deskribapen objektiboa egiten ari dela, iheslariaren inguruan zirkulua osatzeko interes falta dutela adierazten du narratzaileak, eta hiru puntu zerrendatzen ditu interes falta hori azaltzeko, hipotesi gisa. Hirugarren puntuaren ondoren, ordea, oin-oharra gehitzen du autore inplizituak (Hernandez Abaitua, 2008, 226. orr.):

\footnotetext{
Hau egilearen irudiko. Honek ez du nahi esan persegitzaileek posibilitate hauk guziak kontsideratzen dituztenik (edo zituztenik). Agian ez dute egin eta zirkulua ez osatzearen arrazoiak honela sinplifika zitezkeen:

a- Beldur hutsa

b- Azkarrago ezin korritu ahal izatea (38. orr.).
}

Polizien ikuspegitik kontatzeko ezintasuna adierazten da, beraz, ohar honen bidez; espekulatzen ari da, haien jokabidea azaltzerakoan. Bestalde, Olaziregik (1991, 57. orr.) dioenez, poliziak lekuko gazteari egiten dion itaunketaren planoan (B) ere 
ezinezkoa da barrutikako ikuspegi bat ematea eta are fokalizaziorik ez dagoela dirudi. Izan ere, antzerki edo film bateko gidoi forma du B planoak eta gutxieneko presentzia du narratzaileak (Hernandez Abaitua 2008, 219. orr.). Beraz, kontatu baino gehiago, erakutsi edo iradoki egiten da galdeketaren zentzugabekeria eta torturaren mehatxua (edo promesa): "Aquí no se trae a nadie por casualidad» (98. orr.), dio polizietako batek, baina, hain zuzen ere, kasualitatez egokitu zaio han egotea lekukoari. Hura bezala, izugarrikeriaren ikusle edo lekuko bihurtzen da nolabait irakurlea ere, absurdoaren antzerki horretan.

A plano nagusian, esan bezala, hautemangarriagoa da fokalizazioa. Fokua iheslariaren barruan nahiz kanpoan kokatuaz, xehetasun handiz kontatzen dira bere azken segundo, metro eta pausoak, hiltzeko geratzen zaizkionak edo, bestela esanda, hil aurretik eman nahi dituenak terrazan eserita dagoen lekukoarenganaino iristeko. Horixe baita bere helburua; bere heriotzaren lekukoarengana heltzea, hain bakarrik ez hiltzeko:

Baina korrika segitzen duk, han aurrean eseria dagoen tipoarenganantz korrika. Harengan babes bat bilatu nahi bahu bezala. Egia esan, intentzio hori ere ez duk heurea. Hori ere instintiboa duk. Jendea bilatzea, jendearen presentzia sentitu nahi izatea instintiboa duk higan heure burua arriskuan ikusten duan mementuetan. Bestalde ez huke bakarrik hil nahi, eta tipoaren bizarrak, sudurrak, janzkerak, jite osoak hire konfidantza merezi dik. Ba dakik hark bakarrik salba dezakeela hire heriotza -heriotzetik salbatzen bahau ere- haren presentzia beharrezkoa egiten zaik hire heriotza testimoniatzeko. Laurogei eta hamabost, laurogei eta hamalau, laurogei eta hamairu metrotara dadukaan lehendabiziko mahai gainean zerraldo eroriko haizela intuitzen duk, estudiantearen -estudiante bada- edo bizardunaren ondoan behintzat (17-18. orr.).

Iheslariaren konfiantza (eta poliziaren mesfidantza) merezi duen gaztearengananzko korrikaldiaren deskribapen xehea egiten da, beraz, lehen bost kapituluetan, hau da, protagonista bizirik dagoenean. Sinonimoen erabilerak, asindetonek nahiz enumerazio edo metaketek nabarmendu egiten dute militantearen larritasuna, ihesaren erritmo bizia, eta zauritua dagoenean, pauso eta metro bakoitzak eskatzen dion esfortzu ikaragarria: «inguratua, atrapatua, harrapatua, heldua, ikusten haiz dagoeneko» (17. orr.) edo «segundoen ihestea, joatea, hiltzea, ikusten, entzuten, usaintzen duk» (78. orr.).

Kontakizunaren erritmoa geldoa da, bere gorputzaren mugimenduen xehetasun mekaniko eta fisiologikorik txikienak ere adierazten zaizkigulako, zentzumen guztien bidez hautematen duenarekin batera. Ildo horretan, eta oroimena testuratzen duten analepsien azterketari heldu aurretik, ikusmenari eta, zehazkiago, begiradari buruzko irakurketa bat proposatuko dugu; iheslariaren ikuspegitik hautematen diren begiradei buruzko gogoeta txiki bat.

Aldeak alde, jakina da begirada motibo garrantzitsua dela Holokaustoari buruzko literaturan. Hiltzera doanak izugarrikeria ikusten du bestearen begietan; besteak, berriz, ihes egin nahi lioke biktimaren begiradari, interpelatu egin dezakeelako. Adornoren hitzetan: 
La tan oída afirmación de que los salvajes, los negros o los japoneses parecen animales, casi monos, contiene ya la clave del pogrom. Su posibilidad queda ya establecida desde el momento en que el ojo de un animal mortalmente herido da con el hombre. El empeño que éste pone en evitar esa mirada-«no es más que un animal»-se repite fatalmente en las crueldades infligidas a los hombres, en las que los ejecutores tienen continuamente que persuadirse del «sólo es un animal» porque ni en el caso del animal podían ya creérselo (Adorno, 1987, 104. orr.).

Ikara ikusten du iheslariak terrazan eserita dagoen gaztearen eta poliziaren begietan. Bere egitekoa betetzen ari da polizia, baina ikaratuta ikusten du. Oro har, galtzera ohiturik dagoen protagonista irudikatzen du narratzaileak (batez ere, analepsien bidez, ikusiko dugun bezala), eta bere heriotza ere ez da batere heroikoa izango; «Kaka, laga, biba, gora izan daitekeen hots behe bat» ahoskatzea besterik ez du lortzen (88. orr.). Baina bere hiltzailearen begiradarekin topo egiteak erreakzio heroiko bakanetakoa sortzen du iheslariarengan; errebelatu egiten da heriotzaren eta bere borreroaren aurka, aurrera jarraitzeko ahaleginean:

Begi odolez estaliak irekitzen dituk heure hiltzailea begiztatu nahian [...]. Heriotzaren presentziaren beldurra irakurtzen duk haren begietan. Akto sinple bat gehiago bezala egitera doan aktoaren aurrean ikaraturik ikusten duk. [...] Flotatzen, handitzen, puztutzen sentitzen haiz heure heriotzak ikaratzen duen borreroaren aurrean. Biek, heriotza eta hiltzailea mespreziatzen dituk zango zulatua, hustua, odoleztatua hamaikagarren pausoa botatzeko doblatzen duanean (78-79. orr.).

Terrazako gaztearen begiradarekin, berriz, nobelaren hasiera samarrean egiten du topo, eta fidagarria iruditzen zaio: «Orain beldurra irakurtzen duk haren begietan. Ikara. Berarengatik eta beharbada heuregatik ere ikaratua ikusten duk» (36. orr.). Nobelaren amaiera aldera, odoletan arrastaka, alferrikako sakrifizio hori burutzera doanean, berriz begiratzen dio lekukoari, eta darion odola hari eskainiaz abandonatzen du bere burua:

Berrogeitazortzi segundo geratzen zaizkik bakarrik begi bat ireki ahal izateko bestea indarrez hertsiz lekukoarenganako direkzioa asmatzen saiatzen haizenean [...] Ezpainetan, hokotzean, lepoaren zehar bularretik behera joaten zaik bihur zital batetan iturrika galtzeko bonbeatzen duan odola. Lekukoarengana jasotzen duk burua, hautsez, odolez, heriotzez zikindutako aurpegia. 38. Arnasarekin bigunki, sentitu gabe isurtzen duan odola eskaintzen, erakusten diok. 35. Heriotzaren beldurra, ikara, espantua, adierazten ditek haren begiek eta heureak malkoz edo odolez estaliak hersten dituk. Geratzen zaizkian bizitza-segundoak kontatuz abandonatzen haiz (8081. orr.).

Heriotzaren aurreko ikara ikusten du, beraz, polizien eta lekuko gaztearen begietan iheslariak. Ez zaigu, baina, bere sentimenduei eta, oro har, bere izaerari buruzko informazio gehiegi ematen ihesaren narrazioan. Hernandez Abaituak (2008, 242. orr.) azaltzen duenez, oroitzapenak testuratzen dituzten analepsietan agertzen dira bere karakterizaziorako datu gehienak. Garrantzitsua iruditzen zaigu, beraz, analepsi horien 
nolakotasuna aztertzea; zer oroitzapen mota testuratzen den eta nola. Memoria indibidual eta episodikoak narrazioan betetzen duen funtzioaz hausnarketa egitea ahalbidetuko digu horrek.

Oroimena abiarazten duten elementu batzuk agertzen dira kontakizunean, Olaziregiren hitzetan: "Analepsi hauek ihesaren momentuan asoziazioa zilegi egiten duten zenbait elementuren bidez ematen dira: giltza (Michèle), odolaren beroa (Manuel), iheslariaren heriotza (aitaren heriotza), korrikaldia (txikitako pasadizoa)» (Olaziregi, 1991, 50-51. orr.).

Lehenengo kapituluan, «mataderora» joatearen ideiak abiarazten dio oroimena bere heriotzaren kontzientzia hartu duen protagonistari. Izan ere, agintearen (poliziaren) menpe, zereginik ez duela intuitzen du, eta horrek eskolako fraidearen edo aitaren zigorra ekartzen dio gogora:

[...] diagonalean segitzen duk korrika. Idiak mataderorako bidean doazen bezala, haurtzaroan erregela jasotzen zian frailearengana edo zigorra agintzen zuen aitarengana joaten hintzen bezala. Joaten haizen, hoan, joaten doan bezala. Haurrak zortzi, bederatzi, hamar urte ditu behar bada eta «Concha»-n «Alderdi-Eder»-en, hondartzara eraman duen lehendabiziko ranpa pareko aulki batetan, tamarizen azpian, aitaren ondoan, harresiaren kontra lehertuz, gainetik erortzen diren olatuekin jolasean ari diren haurrei begira dihardu (18. orr.).

Donostiako gaztetxoen artean ohikoa den jolas horretan parte hartzea erabakitzen du protagonista haurrak ere; baranda ondoan irautea da kontua, ahalik eta denbora gehien olatuei ihes egin gabe baina lehor. Analepsi horren bidez kontatzen zaigunez, trebeenak batzuetan ez dira bustitzen, eta beste batzuetan bai; eta koldarrenak, berriz, ez dira sekula bustitzen. Protagonista ez da koldarra, baina barandari heldu orduko bustitzen da: «Haurrak bustiak sentitzen ditu oinak sandalia barnetan. Galtzaile 4 bezala, burua makurtuz igotzen du ranpa. Belaunetatik behera busti da, busti zen, busti hintzen bakarrik, baina sandaliak blai-blai hituen eta ba hekien ordurako kresala larruaren hondamena zela» (19. orr.). Aitak emandako belarrondokoak utzitako zurrunbiloaren oroitzapena da ihesi doan unearen kontakizunera itzultzen gaituena (20-21. orr.). Zurrunbiloa sentitzen du orain ere buru barruan, korrika saioaren ondorioz, eta, beraz, bat egiten dute iraganak eta orainak testuan. Hernandez Abaituaren (2008, 228. orr.) hitzetan, errealitate bera balira bezala gainjartzen dira iragana eta oraina, eta ia ez da nabaritzen, kontaketan, oroitzapenetik ihesaldirako pasabidea.

Gainera, dioenez, analepsi hori A plano osoaren mise en abyme bat da (D azpidiskurtsoa bere izendapenaren arabera). Premonitorioa da nolabait: «Olatuak harrapatu eta bustitzen du haurra. Poliziak harrapatzen du iheslaria eta bere odolaz blaitu» (Hernandez Abaitua, 2008, 217. orr.). Busti (konprometitu) egiten da protagonista, ez baita 
koldarra, baina galdu egiten du. Hain zuzen ere, galtzera ohiturik dagoen pertsonaia irudikatzea da, esan bezala, heriotzaren aurreko oroitzapen indibidual eta episodiko horiek betetzen duten funtzio nagusienetako bat, nobelako beste adibide batzuetan ere ikusiko dugunez.

Garrantzitsua da, bestalde, goiko aipu horietako aditz metaketei erreparatzea: «Joaten haizen, hoan, joaten doan» edo «busti da, busti zen, busti hintzen». Bigarren eta hirugarren pertsona gramatikalak eta orainaldia eta iraganaldia nahasten dira hiru aditzeko segida horietan. Hernandez Abaituak (2008, 227. orr.) azaltzen duenez, batez ere analepsietan agertzen dira aditz andana horiek, eta protagonistaren bizipenen eta gogorapenen nahasketa kaotikoarekin dute zerikusia; protagonistak muturreko egoera larri horretan bizi duen barne zurrunbiloa islatzen dute nolabait. Azken kapituluan ez dago halakorik:

[...] protagonista hilda dagoenean bakarrik desagertzen dira aditz errepikatuen andanak, biziak ihes egin dionean eta gogoratzeko eta pentsatzeko ahalmenik ez duenean jadanik. Entzefalograma lauaren isla da. Hau da, mementoko errealitatea eta gogoratutakoa iheslariaren buruan nahasten direnean sortzen dira aditz aldaketen andanak, eta zeharo desagertzen dira iheslaria hil ondoren (Hernandez Abaitua, 2008, 224. orr.).

Ados gaude irakurketa honekin; heriotzaren aurrean, kolpean batzen dira iheslariaren iragana eta oraina, eta haurtzaroko eta gaztaroko oroitzapenak datozkio gogora. Izan zen pertsona haren bizipenak oroitzen ditu izateari uztera doan horrek. Larritasun egoera horretan, norbere baitatik ateratzea eta ia beste bilakatzea iradoki lezakete pertsona aldaketa horiek, hurbiltze eta urruntze frenetikoek.

Gainera, denbora ezberdinen bategiteak adieraz lezake ihes egiteko ahalegin hori ez dela fisikoa bakarrik (poliziengandik), heriotzara doala dakienaren gogoaren ihesa ere badela neurri batean; hau da, heriotzari aurre egin ezinda, iraganera jotzen duela gogoak. Defentsa mekanismo psikologikoa lirateke, beraz, oroitzapen horiek protagonistarentzat, eta baita, neurri batean, bere izatearen nolabaiteko aldarrikapen inkontzientea ere, memoria baita, identitatearen sorkuntzan, subjektuari denboran jarraikortasuna ematen diona (Rosa, Bellelli \& Bakhurst, 2000, 42-43. orr.).

Esan bezala, oro har, ez da iheslariaren ezaugarrietan gehiegi sakontzen, baina analepsi horiek bere nortasunari buruzko informazio apur bat ematen dute; protagonista humanizatzen dute, eta bere heriotza zentzugabea eta alferrikakoa dela adierazten. Helburu hori betetzen du Jacques Prévert-en poeman oinarritutako "Chanson dans le sang» («Song in the blood» ingelesez) abestiak ere. Bigarren eta hirugarren kapituluetako analepsietan agertzen da, Michele, bere maitale izandakoaz oroitzen denean. Michelek emandako giltza da, kasu bietan, oroimena abiarazten duen elementua. Aldean darama iheslariak, korrika doala, eta neska ezagutu zuen eguna gogorarazten dio. Harekin igarotako gauaren oroitzapenaren harira testuratzen da lehen aldiz abestia, ingelesez: 


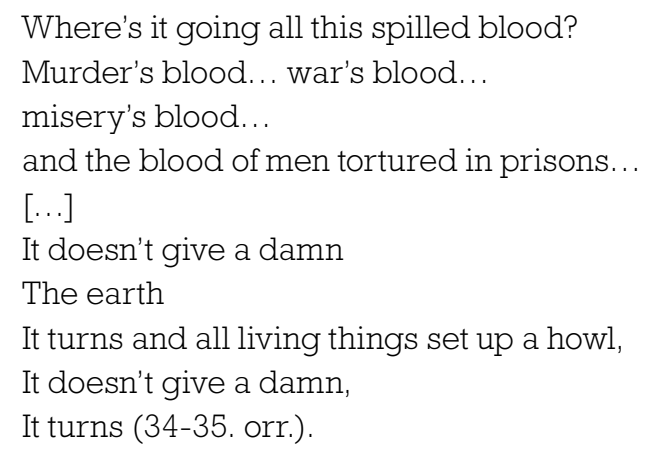

Hernandez Abaituak (2008, 195. orr.) azaltzen duenez, abesti honen agerpena beti dago narratiboki justifikatua (tokadiskoan entzuten dute), nobelaren amaieran izan ezik. Hirugarren kapituluan, protagonista Michelerekin ohean egon zen azken aldiaz gogoratzean agertzen da berriz "Chanson dans le sang» (oraingoan frantsesez), tokadiskoan zegoelako jarrita: «Oú s'en va-t-il tout ce sang répandu [...] elle tourne la terre» (46-47. orr.). Ezberdina da abestia azken aldiz, nobelaren amaieran, agertzen denean. Londres hotelaren kupulako bola handia aipatzen da, adreilu batzuk falta zaizkiola, eta kanta berriz: «It turns the earth [...] It turns with its great pools of blood» (99. orr.). Kasu honetan, ez dago disko jogailurik edo kanta entzuten ari den pertsonaiarik. Filmetako off-eko ahotsaren edo soinu bandaren antzera entzungo litzateke, beraz, nolabait ere hiriak eta munduak biraka jarraitzen dutela adieraziaz, heriotza zentzugabe horren aurrean axolagabe. Hain zuzen ere, axolagabekeria horren kontrako eta «engaiamendu baketsu» baten aldeko aldarria ikusten du Hernandez Abaituak (2008, 269-271. orr.) nobelan, batez ere giltzaren istorioari lotuta (Michelek emandako giltza bat dauka terrazako lekukoak ere), bidegabekeria nagusi den lekuan inor ez dagoela salbu adierazten duelako.

Esan bezala, hirugarren kapituluan ere giltzak abiarazten du memoria; eskuetatik erortzen zaio iheslariari, eta Michelez oroitzen da, lepotik zintzilik zeraman identitate txapaz. Interesgarria da ohartzea identitate txapa horren harira jakin zuela protagonistak Michele judua zela; bere abizena, Manassé, Aljeriako judutar familia zaharrenetako batena zela. Hernandez Abaituak (1983) dioen bezala, Holokaustoarekin lotura bat iradokitzen du judutarren aipamen horrek, alferrik isuritako odolari buruzko kantarekin tartekatuta agertzen delako. «Trauma historikoaren tropo unibertsal» (Huyssen, 2003, 13. orr.) gisa funtzionatzen duen Holokaustoaren oihartzuna dakarkigu, beraz, Micheleren oroitzapenak.

Laugarren kapituluan, zaurituta dagoela, isuritako odolaren beroak Manuelen gaixotasuna dakarkio gogora. Militantzia kide izan zen Manuel, baina gaixotu eta erakundea utzi zuen: «Haren beroa sentitzen duk, sentitzen huen, sentitzen du bere ondoan etzanda...» (66. orr.). Berriz ere, iheslariaren orainaldiko bizipenen eta oroitzapenen nahasketa adierazten du aditz metaketak. Analepsi horretan kontatzen zaigunez, protagonistak ez du Manuelekiko arrangurarik. Hain zuzen ere, ez zuela traidoretzat hartzen esan nahi izan zion kalean familiarekin ikusi zuen batean, baina ez zuen harengana hurreratzea lortu. Hernandez Abaituaren (2008, 204. orr.) arabera, 
Manuelen oroitzapen hori eleberriko unerik hunkigarrienetako bat da eta protagonistaren tolerantzia eta fanatismorik eza adierazten du. Beraz, esan genezake hiltzera doana humanizatzen dutela oroitzapen indibidual horiek, bere alderdi gizatiarra erakusten dutela. Manuelengana eman ez zuen pauso haren oroitzapenak itzultzen du narrazioa ihesaldira:

Aurreratuz bizkarrean jotzea aski hukeela pentsatuz pauso bat ematen duk. Hire bizitzako pausorik luzeena. Hire bizitzako biderik luzeena osatzen duten hogei pausoak emateko geratzen zaian bi minutu eskaseko bizitza zatiarekin konparatzen duk. Hire aurrean, mahai atzean eseria itxoiten dian lekukoarengana daraman gurutzebideari ekiten diok (69-70. orr.).

Alferrik sakrifikatuko den martiria da protagonista ( Baina aurrera jarraitzen duk gelditu gabe, hire bizitzaren sakrifizioaren zahi legokeen jainko bat bezala, eserita itxoiten duen tipoarenganantz» [36. orr.]). Xehetasunez eta gordinki deskribatzen dira laugarren eta bosgarren kapituluetan zauritutako iheslariaren azken ehun metroak, bere gurutze-bidea: «Balaren ukituz azala urratzen zaik, muskuloak bilatzen dizkik, erdibitzen, mozten dizkik tendoiak, ebakitzen zainak, azkenik hezurra ezpalduz, haragi eta zaina nahaste more batetan heldua geratzen den arte» (66. orr.).

Berriz ere, errepikapenek eta metaketek pausoz pauso odolusten ari den gorputz horren sufrimendu eta esfortzu ikaragarria iradokitzen dute: «Pauso bat gehiago [...] pauso bat gehiago»; "[...] egin nahi duen mugimendu lehorra egiteko, tendoi, muskulo, nerbio guztiak presatzen dituen bitartean»; "Izerdi hotz batek bainatzen dizkio, zizkion, dizkik, aurpegia, eskuak eta bizkarra» (65. orr.).

Bosgarren kapituluan amaitzen da gurutze-bide hori, protagonista hiltzean. Azken analepsi batek, ordea, aitaren heriotzaren oroitzapena testuratzen du. Hiltzear dagoela, geratzen zaizkion segundoak kontatuaz abandonatzen da protagonista, eta segundoen kontaketa izarren kontaketarekin lotzen da: haurrak izarrak kontatzen ditu aita salba dadin eskatzeko. Badaki, ordea, ezin dela bete eskatzen duen desira, eta hil egiten da aita: «Begiekin izarrak bilatu hituen berriz ere. Ez hien gorrotorik gordetzen, ohitua hengoen ordurako hire eskariak behin eta berriz desestimatuak ikusten. Orduan heureganako pena besterik ez huen sentitu» (83. orr.). Galtzera ohituta dagoenaren irudia ematen da berriz, eta nobelan lehenengoz protagonistaren izena aipatzen da «se ha muerto el padre de José» (83. orr.).

Gainera, aitaren heriotzari lotuta, Saizarbitoriaren beste lan batzuetan ere garrantzi berezia duten gaiak agertzen dira; hala nola, heriotzaren aurrean sortzen diren pentsamendu morbosoak (Hamaika pauso, 1995), aitarenganako gehiegizko errespetua eta, bereziki, haren herentzia politikoa (Asaba zaharren baratza, 2000): «Laster ehortzi eginen dutela, usteldu eginen dela pentsatzen duk. Ez duala gehiago entzuten haren bozik besoa lepotik pasiaz hau izango da gudaria esaten» (86. orr.). Familian, belaunaldi batetik bestera pasa den memoria komunikatiboaren parte da herentzia politiko hori, eta pentsatzekoa da protagonistaren heriotzak ere anaia gaztearen bizitza baldintzatuko duela, indarkeria eta sufrimendu katea belaunaldiz belaunaldi iraunaraziz. 
Hernandez Abaituak (2008, 212. orr.) azaltzen duenez, zalantzazkoa izan daiteke eskolako pasarteetan (F planoan) agertzen den haurra iheslaria bera den, txikitan, ala bere anaia gaztea. Iheslaria dela ondorioztatzen badu ere, pasarte batzuek aditzera eman lezakete $\mathrm{F}$ planoko haurra $\mathrm{D}$ planoan plazan jolasean agertzen diren haurretako bat dela, besteak beste, berdin jantzita doazelako, bata edo mantal beltzez. Hernandez Abaituaren arabera, zirkulartasun horrek errealitatea sorgin-gurpil batean sartuta dagoela adieraz lezake. Nobelaren zirkulartasuna eta izaera antiutopikoa nabarmentzen ditu Kortazarrek (2013, 260. orr.) ere. Olaziregik azaltzen duenez, berriz, F planoan, "orainaldiaren erabileragatik eta denboraren zehaztasun ezagatik, narratzaileak hemen 'oraindik orain' gertatzen den egoeraren salaketa egin nahiko lukeela pentsa daiteke» (Olaziregi, 1991, 51. orr.). Hain zuzen ere, luzaroan iraunarazi du «sorgin-gurpil» hori Estatuaren nahiz ETAren indarkeriak.

Bereziki esanguratsuak dira, ildo horretan, plazako haurren jolasak: heroi-martiria izan nahi du batek "Ni ere hil egingo naute handia izatean» (92. orr.); polizia eta lapurretara ari direla, beste batek «Zeintzuk dira onak?» (56. orr.) galdetzen du. Eta bereziki esanguratsua da, halaber, F planoan, haurrak eskolan jasaten duen zapalkuntza politiko kulturala; maisuak egiten dion iraina (bere abizen euskalduna dela medio) eta ezartzen dion zigorra. Espainiako banderari buruzko doktrina diktatzen ari zaien fraideari ikurrinaren koloreak aipatzen dizkio haurrak, aitak erakutsi dion bezala, eta zigor gisa, bostehun aldiz kopiatu beharko du «Los rojos separatistas fusilaron la imagen del Sagrado Corazón en la Capilla del colegio». Ikasgelan bakarrik geratzen denean, bi lumaz saiatzen da zigorra betetzen, azkarrago bukatzearren, baina ez du lortzen: «Ez zait kabitzen esaten du galtzen ohiturik dagoenaren erresignazioarekin bi lumetako bat pupitre gainean utziaz» (74. orr.). F planoko haurra iheslaria bera dela onartuz gero, esan genezake agintearen menpe galtzera ohiturik dagoen antiheroiaren irudia indartzen dela hemen ere, eta gorago azaldutako analepsietan bezala, alferrik hiltzera doan protagonista humanizatzen dela, bere iraganeko pasarteak testuratuaz.

Laburbilduz, haurtzaroko eta gaztaroko oroitzapenek, bere indar afektiboaren ondorioz, humanizatu egiten dute galtzaile gisa agertzen den protagonista. Erakundean noiz eta nola sartu zen esplizituki kontatzen ez den arren, fokalizazioren erabilera horren ondorioz, posible zaigu haren larruan sartzea eta neurri batean «gudari» izatera zerk eraman duen ulertzea. Beraz, 1990eko hamarkadaz geroztik batez ere terroristaren ikuspuntua landu duten nobelen (Olaziregi, 2011) aitzindari litzateke 100 metro, ekintzaile-biktimaren ikuspuntua testuratzen duen neurrian.

\section{MEMORIA KOMUNIKATIBOAREN SORKUNTZA: POLIFONIA ETA IKUSPEGI ANIZTASUNA 100 METRON}

Memoria indibidualetik kolektibora, gizarte testuingurua nola irudikatzen den aztertzeko ere, baliagarria izan daiteke nobelaren ezaugarri formalei erreparatzea, ikuspegi narratologikotik. Esan bezala, iheslariarengan jartzen da batez ere foku narratiboa A planoan, bere azken 100 metroak kontatzeko. Nobela osatzen duten gainerako 
planoek, ordea, ikuspegi eta diskurtso mota ezberdinak testuratzen dituzte. Polifonia eta ikuspegi aniztasun hori memoria ikasketen ikuspegitik interpretatuko dugu, eta 100 metron memoria komunikatiboaren sorkuntza prozesua irudikatzen dela iradokiko.

Horretarako, Lasagabasterrek (1989) Bakhtinen teorian oinarrituta egiten duen irakurketa hartuko dugu abiapuntu. Bi ezaugarri nabarmentzen ditu 100 metron, polifoniari eta testuartekotasunari dagokienez: alde batetik, «sortutako» eta «sartutako» testuen («textos generados» eta «textos incorporados») konbinazioa; hau da, nobelan bat egiten dute testu literarioak eta egileak eransten dituen albisteek, iragarkiek edota abestiek. Bestetik, sistema linguistiko ezberdinen erabilera; izan ere, abestietako ingelesaz eta frantsesaz gain, gaztelerak garrantzi berezia du testuan, euskararekin batera. «Sartutako testuak» (kantak izan ezik), gazteleraz daude. "Sortutakoa», berriz, euskaraz narratzailearen ahotsa bada, eta ele bietan pertsonaien ahotsak direnean. Lasagabasterrek dioenez, hizkuntzen erabilera horrek nobela idatzi zen garaiko Euskal Herriko errealitate soziolinguistikoa islatzen du. Egiantzekotasuna ez da, baina, euskara eta gaztelera modu horretan nahasteko arrazoi nagusi eta bakarra:

Cuando en 100 metro los policías hablan no la lengua de su creador, el euskara, sino la suya de ellos, el castellano, no lo hacen, pues, por imperativo de la verosimilitud novelesca. No son razones lingüísticas las que imponen a los policías de la novela el tener que hablar castellano. Las razones por las que el lector euskaldun se resiste a aceptar que los policías hablen euskara no son lingüísticas; son, en el fondo, socio-políticas (la razón del «que se vayan») (Lasagabaster, 1989, 334. orr.).

Ikuspegi horren arabera, elkarren aurkako bi munduren arteko zatiketa islatuko luke dialogismo horrek. Esan bezala, Bakhtinen teoriaren arabera, hizkera, diskurtso eta mundu ikuskera ezberdinak bateratzen dira nobeletan, harreman dialogikoan; eta Erllek (2011) dioenez, memoriaren errepresentazioari ere eragiten dio honek, memoria ezberdinak ager daitezkeelako aurrez aurre, memoriaren perspektiba aniztasuna («mnemonic multiperspectivity») sortuaz. Ildo horretan interpretatuko ditugu nobelako planoetako diskurtsoak eta horien arteko kontrastea.

Hasteko, bereziki interesgarri deritzegu D planoko herritarren iruzkinei; ahots anonimoak txertatzeko modu horri. Donostiako kaleetako eszena arruntak irudikatzen dira hilketaren ostean, hurrengo egunean. Herritarrek gertatutakoa komentatzen dute kafetegian, lanera bidean, erosketetan edota txikiteoan, tragedia bateko korua osatuko balute bezala. Pertsonaia kolektiboa da Hernandez Abaituaren arabera: «[...] azpidiskurtso honetan fokalizazioa oso aldakorra da, hegan dabil hiriko gauzak eta pertsonaia anonimoak deskribatuz, batetik bestera etengabe jauzika, zati honetan protagonista kolektiboa dela azpimarratzeko: jendea eta hiria» (Hernandez Abaitua, 2008, 220. orr.).

Beraz, ahots anonimo horiek gizartearen (edo gizartearen parte baten) jarrera islatzen dutela esan genezake. Oro har, ez diote aparteko garrantzirik ematen militantearen hilketari; euren eguneroko bizimoduak aurrera darrai. Gaztearen heriotzaren alferrikakotasuna iradokitzen du, esan bezala, nobelan behin baino gehiagotan agertzen den kantak ere («It turns the earth [...] It turns with its great pools of blood»). 
Herritarrek gertatutakoaz duten informazioa oso da azalekoa, zehaztu gabea. Kontuan izan behar da, noski, Diktaduraren amaiera aldeko gizartea irudikatzen duela nobelak -«San Sebastian Verano 74» aipatzen da (91. orr.)-, eta beraz, ez dagoela informazio eta adierazpen askatasunik. Ezin dugu ahaztu, halaber, 100 metro nobelak berak arazoak izan zituela zentsurarekin garai hartan.

Poliziaren eta, oro har, erregimenaren ikuspuntua ematen duten hedabideen aurrean, herritar anonimoen artean zabaltzen den informazioa ahozko komunikazioan oinarritutakoa da. Hain zuzen ere, egunerokotasunari lotutako hainbat eszenatan agertzen diren ahots horiek elkarrekiko harremanean sortzen duten informazio fluxuak memoria komunikatiboaren funtzionamendua islatzen duela uste dugu. Izan ere, azaldu dugunez, memoria komunikatiboa eguneroko komunikazioan oinarritzen den memoria kolektiboa da, eta ahozko historiari dagokio (Assmann, 1995).

Pentsa genezake kasu honetan denbora tartea mugatuegia dela memoria komunikatiboaz jarduteko, oso berria delako komunikazio ekintza horien bidez jakinarazten den gertakaria; azken finean, bezperan hil dute iheslaria. Ez da, baina, hilketa kasu bakana. Aitzitik, garaiko euskal gizartea horrelako gertakarietara nahiko ohituta zegoela adierazten dute kaleko jendearen iruzkinek: «Nada que se han chingado a uno» (23. orr.), «-Hortxe plazan kiskali zitekean. -Beti zegok zerbait. Eta hiri zer pasatzen zaik. -Ez diat begirik hertsi erreuma zikin honekin» (24. orr.), «-Aurtengoan badituk hildako batzuk. -Bai. Asko. -Kriston morala zeukatek» (27. orr.). Ildo honetan esan genezake euskal gizartean urte askoan luzatu den indarkeria egoeraren memoria komunikatiboa islatzen duela nobelak, prozesu gisa, komunikazio ekintza horien bidez.

Ausardia aitortzen diote batzuek militanteari: «-Desde luego huevos no les faltan [...] -Es que meterse aquí es meterse en una ratonera. -Podía haberse metido en un portal. Y salir por el tejado. -Hitz egitea erraza duk. -Ez, ez. Potroena ez dik inork diskutitzen» (22. orr.). Baina, oro har, nahiko axolagabe agertzen dira herritarrak; iheslari gaztearen odolaz zikindutako plazaren inguruko tabernetan ardoa edaten dute helduek, eta haurrek plazan bertan jolasten.

Hernandez Abaituaren (2008, 202-203. orr.) arabera, herritarren artean, emakumeak dira indiferenteak ez diren bakarrak. Gupida eta gertutasuna erakusten dute, baina baita nolabaiteko fribolitatea edo arinkeria ere: «Sekretoak kontatzeko bozaz mintzo dira, ukalondoekin saihetsean ukituz, beren gona plisatuak izter artean bilduz. Ahoak belarrietara hurbiltzen dira. -Guapoa ahal hunan. -Guapoa ez zekinat. Interesantea dun hitza behar bada» (59. orr.).

Giro politiko nahasia dela eta, zuhurtzia iradoki lezake apika isilpekotasun horrek. Baina, oro har, J. Assmannen (1995) definizioaren arabera memoria komunikatiboak dituen ezaugarri nagusiak antzeman ditzakegu emakume anonimo horien elkarrizketetan: ez da informazio espezializatua, elkarrekiko harremanean moldatzen da eta ez dago forma edo antolabide finkorik. Oinarri sendorik gabeko txutxu-mutxuak ere agertzen dira, Bretxako merkatuan dabiltzan emakumeen ahotan: 
-Alde alde hil egin behar naute eta esaten omen zinan.

-Gizajoa.

-Beste norbait zauri ote zitekeen beldurrez gizajoa.

-Ba nik bere burua hil zuela entzun dinat. Pedrori ez zekinat nork...

-Tira, tira.

$[\cdots]$

-Beti zeukanagu zerbait.

-Gizajoek nahi diten zerbait, baina hauekin ez zegon ezer egiterik.

-Hala den.

$[\ldots]$

-Bai neska hik ere ezagutuko hunan horren izeba.

-Semea ere horrelako gauzetan sartua ibili zitzaiona (55. orr.).

Gizajoarenarekin batera, heroi-martiriaren irudia ere nabarmentzen da emakumeen arteko elkarrizketa horietan: «-Che Guevara ematen omen zinan. -Ba Anek Jesukristo esan din. -Berdin den neska, Che Guevara edo Jesukristo. -Beharbada andregaia izanen zinan. -Beharbada. Gajoa. -Zergatik gajoa. Nahi hunan hik» (60. orr.). Plazako haurren jolasek ere adierazten dute heroi-martiriaren irudi hori, aurreko atalean azaldu bezala, handitzean bera ere hil egingo dutela esaten baitu haurretako batek (92. orr.).

Eszena horiekin, Donostiari buruzko informazio turistikoa tartekatzen da (E planoa). Idazleari esker dakigunez, Jose Maria Donosty-ren ${ }^{5}$ San Sebastian y Guipuzcoa (1972) gidakoak dira nobelan txertatzen diren pasarteak, nolabait ere Donostia friboloa, turistikoa, burges txikia irudikatzeko. Alde Zaharrari buruzko aipuak agertzen dira: «Donostiarras y forasteros aman esta parte vieja de la ciudad precisamente por el contraste que ofrece con la parte más moderna y amplia de sus ensanches» (100 metro, 56. orr.; $S S y G, 44$. orr.). Taberna-giro alaia nabarmentzen du gidak:

5 Javier Ma Sadak (2002, 164. orr.) azaltzen duenez, Leonardo Fernandez Eleicegui (1887-1977) zen Jose Maria Donostyren benetako izena, eta Donostiako kronista ofiziala izan zen 1950 urteaz geroztik. Hainbat aldizkaritan idatzi zuen (Revista Euskalerria, La Voz de Guipúzcoa, El Pueblo Vasco, ABC, El Imparcial, Vida Vasca, La Baskonia, La Voz de España, La Hoja del Lunes, eta abar), eta Donostiako Udaleko Informazio Buletineko zuzendari izan zen. Besteak beste, Marinos guipuzcoanos en los siete mares, San Sebastián y Guipúzcoa eta San Sebastián en color liburuak argitaratu zituen. 
Hay que ver la Parte Vieja a la hora crepuscular del anochecer, en pleno chiquiteo, cuando los donostiarras -y quienes no lo son-, llenan sus tascas y tabernas, bares, restaurantes y «sociedades populares» o gastronómicas, tan numerosos, ámbitos todos ellos rezumando euforia, y ese buen humor sano, jocundo y característico que tanto agrada al forastero y que se desborda por sus animadas calles (100 metro, 91. orr.; SSyG, 44. orr.).

Alde Zaharraren erdigunea da Konstituzio plaza, nobelako espazio nagusia, eta honi buruzko aipua ere testuratzen da, turismo gidatik hartuta ${ }^{6}$. Leku hori garai batean zezen plaza izan zela aipatzen da, eta hainbat kritikarirentzat esanahi sinboliko berezia dauka horrek, nolabait ere (alferrikako) sakrifizioarekin lotutako espazio gisa agertzen delako; aldeak alde, zezenketetako ikuskizun odoltsua gogoraraz diezagukeelako iheslariaren heriotza gordinak (Aldekoa, 2008; Kortazar, 2013; Hernandez Abaitua, 2008). Protagonistaren ihesaren kontakizunean (A planoan) ere aipatzen diren balkoi zenbakituen inguruko azalpena ematen du gidak:

La plaza rectangular que en pasados tiempos fue el ágora y centro comercial social y festejero de la ciudad, ofrece la particularidad de que los dinteles de las puertaventanas de las fachadas de sus casas están correlativamente numerados en razón de la servidumbre a que estaban sujetos sus correspondientes balcones a servir de palco en la celebración de las corridas de toros... (100 metro, 24. orr.; SSyG, 44. orr.).

Bestalde, Kontxaren edertasunari buruzko aipuak ere txertatzen dira 100 metron, Jose Maria Donostyren gidatik hartuta: «Pasearse por la Concha es placer de seres privilegiados. En ciudad alguna luce la mujer más y mejor su belleza y sus galas, por la sencilla razón de que el marco y el ambiente conspiran a realzarla» (100 metro, 90. orr.; $S S y G, 4$. orr.), edota «El paisaje urbano más conocido característico noble y espacioso de la capital veraniega de España, es sin disputa el de la Concha. A su extenso paseo como por intuición acude el forastero" (100 metro, 59. orr.; SSyG, 38. orr.). Munduko beste pasealeku ezagun batzuekin ere alderatzen da Kontxa, bere edertasun paregabea laudatzeko (100 metro, 89. orr.; $S S y G, 38$. orr.).

Donostia turistiko eta friboloa irudikatuko lukete, beraz, Jose Maria Donostyren gidatik hartutako pasarte horiek, herritarren iruzkin batzuek bezala. Gidak eskaintzen duen argazki idealizatu horrek talka egiten du, ordea, plazako gertakari gordinarekin. Nobela osoa markatzen du planoen arteko talkak, kontrasteak; iheslariaren hilketaren kontakizunak talka egiten du, esaterako, C planoko albistearekin (polizia txostena dirudi).

6 Badago nobelan plazari buruzko aipu bat gidakoa dirudiena baina Donostyren (1972) gidan aurkitu ez duguna: «La Plaza de la Constitución, ahora conocida con el nombre de Plaza 18 de Julio, abre veintiún arcos en sus fachadas orientadas al Norte y al Sur. Nueve arcos más dos laterales (calles Pescadería e Iñigo), dan acceso a las viviendas que constituyen el lienzo oriental. Y al viejo Ayuntamiento se accede a través de cinco arquerías, que delimitan seis macizos y cuadrados soportes. Graciosas pasarelas...» (100 metro, 27-28. orr.). Baliteke pasarte hori beste argitalpen batetik hartua edota asmatua izatea. Bereziki esanguratsua litzateke Saizarbitoriak sortutakoa izatea, plazaren izen aldaketa aipatzen delako esplizituki, eta nolabait ere aldaketa horren esanahi sinbolikoa azpimarratuko litzatekeelako. 
Areagotu egiten da planoen arteko kontraste hori bosgarren kapituluaren amaieratik aurrera, hau da, iheslaria hil ondoren. Minutuak pasa ahala itzaltzen ari den gorpua ospitalera daramatela kontatzen zaigu. Aldi berean, bere senideak, egunero bezala, ordu horretan egiten ari direnaren berri ematen zaigu; anaia nagusia lanera doa, anaia txikia eskolara, eta ama erosketak egitera. Eta tartekatu egiten dira lekuko gazteari egiten ari diren galdeketako pasarteak ere:

Berrogeitabost minutu pasa dira. Hire amak egunero bezala esne boteila esnedunei utzi ondoren San Vicente-n sartzen duk bisita bat egitera. La voz de Guipuzkoa dantza musika selekzio bat ematen ari duk. Ez dik hire heriotzari buruz deusere esan. Berrogeitazazpi minutu. Radio Reloj le saluda. Buenos días. Sabeleko zuloa jostorratz lodi batez josten ari zaizkik. Está usted en la cama? Buenos días. Azken odol tantoak isurtzen dituk. Si está usted trabajando, buenos días también. Radio reloj le saluda. Berrogeitahamar minutu. Comienza a llover suavemente sobre la ciudad, una lluvia casi imperceptible pero que moja amigos. La temperatura en la Avenida de España es de quince grados. Azken odol tanto ureztatuak. Cuando en el reloj de nuestros estudios son exactamente las ocho horas cincuenta y tres minutos. Berrogeitahamairu minutu, berriz ere besapetik eta izterretatik helduaz airean altxatzen hautenean (97-98. orr.).

Deigarria da heriotzaren ondorengo minutuetan, fokuaren etengabeko mugimendu horietan irratiak sortzen duen kontraste efektu bortitza. Hernandez Abaituak (2008, 208-209. orr.) azaltzen duenez, seigarren kapituluan, irratiaren presentzia etengabeak batzen ditu leku guztiak, eta ez da adierazten irrati aparailua non dagoen edo nork entzuten duen.

Modu batean baino gehiagotan testuratzen dira irratiko ahotsak. Alde batetik, irratiko programazioari buruzko oharrak egiten ditu narratzaileak: «Kaiean barkoak sartzen hasiak dituk gehienak arrantza eskasarekin. Radio San Sebastian-en eguneroko programazioa leitzen ditek. Bost minutuz komertzialak esan ondoren, notiziarioari ekiten diote. Ez ditek hire heriotzaren berri ematen» (96. orr.). Ospitalean «txukuntzen» ari diren gorpuari buruzko azken xehetasunak ematerakoan, ordea, esatariaren ahotsa da zuzenean kontrapuntua egiten duena, aurreko aipuan ikusten denez. Are errealitate gordinagoa irudikatzen da horrela, ospitaleko mahaian etzanda dagoen gorpuari egunonak ematen ari den esatariaren ahots friboloa kontrajartzen zaiolako, berriz ere, munduak (axolagabe) aurrera jarraitzen duela adieraziaz.

Seigarren kapituluan irratiaren nonahikotasuna irudikatzen dela esan genezake, plano ezberdinetan hedatzen delako, ikus-entzunezko lanetan off-eko ahotsa bezala (eta beraz, zinemaren eragina nabaritzen da, apika, soinuaren hedapena irudikatzeko moduan ere). Nonahikotasun hori interpretatzerakoan, kontuan izan behar da, noski, irratiak diktadura garaian zuen garrantzia. Izan ere, bere gertutasunaren eta berehalakotasunaren ondorioz, informazioa eta propaganda gizarteratzeko hedabide nagusienetakoa zen: «El franquismo estaba especialmente interesado en controlar la radio, dada su capacidad de penetración ideológica y su continua expansión, reflejada en el aumento del número de emisoras en el País Vasco y Navarra en estos años» (Pablo, 
2009, 395. orr.). Kontrol hori norainokoa zen ulertzeko nahikoa da gogoraraztea albisteak emateko derrigorrezkoa zela Radio Nacional de Españarekin konexioa egitea (Pablo, 2009, 398. orr.).

Seigarren kapituluan, militantea hil osteko minutuetan, irratiak ematen duen kontrapuntu hori (edo antzekoa) ematen du egunkariak aurreko kapituluetan, batez ere C eta D planoetan. Egunkaria erosten eta irakurtzen agertzen dira herritarrak: «Periodikoak kafetegietako, bulegoetako, formikazko mahai gainetan» (23. orr.). Prentsaren (eta beraz, diskurtso frankista ofizialaren) nonahikotasuna iradokitzen da hemen ere. Kaleko ahots anonimoek diotenez, egunkariak ez dakar ezer bezperan gertatutakoaz, herritarren ahotan bolo-bolo dabilen albistea izan arren.

Ez dakigu C planoak zatika testuratzen duen albistea zein hedabidetan zabaltzen den edo nork irakurtzen/entzuten duen. Polizia txostena dirudi eta, beraz, gertakariari buruzko bertsio ofiziala ematen du, A planoko kontakizunarekin kontrastea eginaz eta poliziaren eta hedabideen gezurra agerian utziaz. Nonahiko ahotsa da bertsio ofiziala, baina talka egiten du A planoko kontakizunarekin eta $\mathrm{D}$ planoko herritar anonimoen zurrumurruekin.

\section{ONDORIOAK}

Plano ezberdinen arteko kontrasteak, ikuspegi eta diskurtso aniztasun horrek, izaera polifoniko nabarmena ematen diote 100 metrori, eta hori esanguratsua izan daiteke nobela memoria ikasketen ikuspegitik interpretatzerakoan. Memoria indibidualak aztertzean ikusi dugu A planoan, militantearen ihesaren kontakizunean, analepsien bidez testuratzen diren oroitzapenek funtzio garrantzitsua betetzen dutela bere karakterizazioari dagokionez: heriotzaren aurrean azaleratzen diren haurtzaroko eta gaztaroko oroitzapenek alferrik hiltzera doan protagonista humanizatzen dute.

Baina, ihesaren kontaketan fokua batez ere militantearengan jartzen den arren, eta memoria indibidualaren bidez protagonista humanizatzen bada ere, sinplekeria litzateke 100 metro nobela abertzaletzat edo Espainiaren aurkako nobelatzat hartzea, argitaratu zenean zenbaitek (besteak beste, zentsura frankistak) interpretatu zuten bezala, sarreran azaldu dugunez. Gatazkaren unean bertan heltzen dio gatazkari, eta ildo horretan «nobela testimoniala» dela esan genezake, Sarrionandiaren (1979) hitzak geure eginaz. Ez da tesi nobela, hori baino konplexuagoa da, eta ezer adieraztekotan, heriotza horren alferrikakotasuna iradokitzen du; gizarteak, munduak aurrera jarraitzen duela, ia axolagabe.

Bestalde, plano ezberdinen arteko kontrasteak frankismo amaierako gizartearen egoera konplexua islatzen du: diskurtso frankista ofiziala gizarteratzen duten hedabideen aurrean, kaleko eguneroko komunikazioan oinarritutako (des)informazioa zabaltzen da herritarren artean, eta esan genezake ahots anonimo horiek, ikuspegi askotariko baina herren horiek, gatazkaren eta zapalkuntzaren memoria komunikatiboaren sortze prozesua irudikatzen dutela, hiriko hainbat lekutara hedatzen diren elkarrizketa banal eta hitz aspertu horien bidez. 


\section{ERREFERENTZIAK}

Adorno, T. (1987). Minima moralia: reflexiones desde la vida dañada. Madril: Taurus. Assmann, A. (2004). Six Forms of Memory in Shakespeare's Hamlet. In C. Bode, S. Domsch \& H. Sauer (arg.), Anglistentag 2003 in München. Proceedings (325-334. orr.). Trier: WVT Wissenschaftlicher Verlag Trier.

Assmann, J. (1995). Collective memory and cultural identity. New German Critique, $65,125-133$.

Bal, M. (1990). The Point of Narratology. Poetics Today, 11(4), 727-753.

Bal, M. (1999). Close reading today: From narratology to cultural analysis. In W. Grünzweig \& A. Solbach (arg.), Grenzüberschreitungen: Narratologie im Kontext / Transcending Boundaries: Narratology in Context (19-40. orr.). Tübingen: Gunter Narr Verlag Tübingen.

Colmeiro, J. (2005). Memoria histórica e identidad cultural: de la postguerra a la postmodernidad. Bartzelona: Anthropos.

Donosty, J. M. (1972). San Sebastián y Guipúzcoa. Leon: Everest.

Erll, A. (2009). Narratology and Cultural Memory Studies. In S. Heinen \& R. Sommer (arg.), Narratology in the Age of Cross-Disciplinary Narrative Research (212-227. orr.). Berlin/New York: Walter de Gruyter.

Erll, A. (2011). Memory in culture. Basingstoke: Palgrave Macmillan.

Genette, G. (1972). Figures III. Paris: Seuil.

Halbwachs, M. (1994) [1925]. Les cadres sociaux de la mémoire. Paris: Albin Michel.

Halbwachs, M. (1968) [1950]. La mémoire collective. Paris: Presses Universitaires de France.

Hernandez Abaitua, M. (1983). Saizarbitoriaren «100 metro»ren semantikaz ohar batzu. Jakin, 29, 173-185.

Hernandez Abaitua, M. (2006). Literatura engaiaturantz rock \& rollaren eskutik. In I. Egaña \& E. Zelaieta (arg.), Maldetan sagarrak: Euskal gatazka euskal literaturan (75-92. orr.). Bilbo: Udako Euskal Unibertsitatea.

Hernandez Abaitua, M. (2008). Ramon Saizarbitoriaren lehen eleberrigintza. Bilbo: Euskal Herriko Unibertsitateko Argitalpen Zerbitzua.

Huyssen, A. (2003). Present Pasts: Urban Palimpsests and the Politics of Memory. Stanford: Stanford University Press.

Kortazar, J. (1980). R. Saizarbitoriaren 'Ehun metro'. Jakin, 13, 142-151.

Kortazar, J. (2013). Todo lo que siempre quiso saber sobre '100 metros' y nunca se atrevió a preguntar. In J. Kortazar (arg.), Homenaje: Saizarbitoria y su mundo. Cuadernos de Alzate, $46-47$ (251-261. orr.). Madril: Editorial Pablo Iglesias.

Lasagabaster, J. M. (1989). La novela vasca al borde de la realidad. In Askoren artean, Congreso de Literatura. Hacia la literatura vasca. II. Congreso Mundial Vasco (319-346. orr.). Madril: Castalia.

Neumann, B. (2010). The Literary Representation of Memory. In A. Erll \& A. Nünning (arg.), A Companion to Cultural Memory Studies (333-343. orr.). Berlin/ New York: De Gruyter.

Nünning, A. (1997). Crossing Borders and Blurring Genres: Towards a Typology and Poetics of Postmodernist Historical Fiction in England since the 1960s. European Journal of English Studies, 1(2), 217-238. 
Nünning, A. (2004). Where Historiographic Metafiction and Narratology Meet: Towards an Applied Cultural Narratology. Style, 38(3), 352-375.

Olaziregi, M. J. (1991). Fokalizazioa: hurbilpen teorikoa eta zenbait aplikapen euskal narratiban. ASJU, 25(1), 3-63.

Olaziregi, M. J. (2001). Ramon Saizarbitoriaren unibertso literarioa. Bilbo: Labayru Ikastegia.

Olaziregi, M. J. (2002). Euskal eleberriaren historia. Bilbo: Labayru Ikastegia \& Amorebieta-Etxanoko Udala.

Olaziregi, M. J. (2011). Basque Narrative about the Spanish Civil War and Its Contribution to the Deconstruction of Collective Political Memory. In S. Ott \& S. de Pablo (arg.), War, Exile, Justice and Everyday Life, 1936-1946 (107132. orr.). Reno: Center for Basque Studies, University of Nevada, Reno.

Rosa, A., Bellelli, G. \& Bakhurst, D. (arg.) (2000). Memoria colectiva e identidad nacional. Madril: Biblioteca Nueva.

Rothberg, M. (2009). Multidirectional memory: remembering the Holocaust in the age of decolonization. Stanford: Stanford University Press.

Sada, J. M. (2002). Historia de la ciudad de San Sebastián a través de sus personajes / Donostiako hiriaren historia: bertako pertsonaien bidez. Irun: Alberdania.

Sarrionandia, J. (1979). 100 metro. Zeruko Argia, 829, 29. orr. Hemendik hartua: http://kritikak.armiarma.eus/?p=2922

Torrealdai, J. M. (2000). Artaziak: euskal liburuak eta Francoren zentsura, 19361983. Zarautz: Susa.

\section{Ramon Saizarbitoriaren nobelak}

Saizarbitoria, R. (1976). 100 metro. Donostia: Kriseilu.

Saizarbitoria, R. (1995). Hamaika pauso. Donostia: Erein.

Saizarbitoria, R. (2000). Asaba zaharren baratza. Gorde nazazu lurpean (401-464. orr.). Donostia: Erein. 